\title{
CONTRIBUTION TO THE FREE TIME IN HOSPITALIZED CHILDREN IN CZECH REPUBLIC
}

\author{
${ }^{\mathrm{a}}$ MARTIN DLOUHÝ, ${ }^{\mathrm{b}}$ LADISLAV POKORNÝ, 'VĚRA \\ KUHNOVÁ
}

Charles Unicersity in Prag, Faculty of Education, Department physical education, M.D. Rettigové 4, 11639 Prag, Czech Republic.

email: ${ }^{a}$ martin.dlouhy@pedf.cuni.cz

bladislav.pokorny@pedf.cuni.cz, ${ }^{c}$ vera.kuhnova@pedf.cuni.cz

Abstract: The article deals with the problem of free time hospitalized children. Characterizes children's free time and analyzing psychotherapeutic support options pediatric patients. Also draws attention also to this new innovative way psychterapeutické support and leisure activities such as children of cancer patients through their visits to the Zoo. Highlights the effectiveness of this type of leisure time as an effective psychotherapeutic support these children. Describes this possibility, which has become an established tradition in hospital in Brno in the oncology clinic at Black fields. Documented so extremely interesting use of free time, which featured a form of psychotherapy has a very positive meaning for hospitalized pediatric patient. Significantly contributes to mental balance and well-being child patient, which is currently in the oncology area (and obviously not in it) extremely important in the overall treatment process.

Keywords: leisure, hospitalized children, psychotherapy

\section{Introduction}

A leisure time might be characterized as an opposite of a required work and responsibilities. A time when a man can chose his activities optionally and they bring a feeling of satisfaction and relaxation (Pávková et al., 2005). These activities restore and develop his or her physical and spiritual abilities at the same time. In this time a human is becoming a one's own man, he or she belongs one's own the most. All the activities that are carried on, even a man is undertaking them for himself or for others, based on an inner initiative or on an interest (Němec et al., 2002).

A leisure time of children in a hospital is a time, when children are not expecting any examination, operations or treatment procedures. When they do not need to fulfill any school duties, it is a time when a child can dispose of activities freely, based on a child judgment to a certain extant - based on an environment a child is in and based on an actual patient mood and a psychical state.

If a child in a leisure time in a hospital is left "just so", without any notice, a leisure time becomes an empty time, in which will be a solid space for a boredom state and for bothering. But based on an environment and on a situation the child is in, even for nostalgia, an anxiety, and for inquietude. To not let this happened the children in their leisure time are under a supervision not only of hospital staff, but even under a supervision of professionals from other supporting professions such as social pedagogues, schoolmasters in hospital schools, psychologists, game specialist, and volunteers: high school and university students, hospital jesters etc.

Since 1994 a survey of Endowment Fund Klíček In Czech Republic has been carried out in a children departure in hospitals. All the children departures in the Czech Republic have been questioned. The questionnaires were filled in by responsible employees of a certain department. The text containing their answers and it is therefore their presentation of an achal state of children departments in the Czech Republic. Concrete results of this surfy are available from 29. 10. 2007 on web sites www.detivnemocnici.cz ${ }^{1}$.

On a question how is the children leisure time shielded in hospital, doctors and nurses named partly material equipment: televisions in bedrooms and in playrooms, videos, DVDs, etc. An important part of the leisure time was attributing to hospital schools, to a role of playing specialists and volunteers, and to special activities (theater performances, visiting of zoo, etc.). From parents of sick children point of view is at the very first place a child health state, a quality of medical treatment, and a

${ }^{1}$ Královec, J., Královcová, M. Nadačni fond Kliček. [online] retrieved 2013. from: www.klicek.org/index2.htm fast recovery, so that all what is closely connected with their quality of life. A somatic aspect is significantly affected by a good psychical condition that participants on the leisure time usage.

A function and possibilities of the leisure time defines Opaschowski (2001). As a ground functions he sees recreational functions: recovery and relaxation; compensative disappointments and frustration elimination; pedagogical and further educational, contemplation - seeking for a meaning of life and its spiritual development; communicational social contacts; participation - participate in society running process; integration family life stabilization and in growth into society organisms; en cultural - cultural development of one's own, creative expressions trough art, sport, and other technical activities.

From a hospitalized child point of view a recreational function, i. e. recovery and relaxation after medical treatments, examinations, procedures, and even after school duties. On the other hand even a fulfillment of school duties and elaboration of home works might have, under certain circumstances, a recovery character. Family visits and a time spend with relatives might be a part of a relaxation; on the other hand it might be exhausting even if a visit is nice and welcome.

Exhaustion state might occurs when an organism is weakened; a child can be easily tired out; during a visit an arguing might occurs, at this case the visit just deepens stress and frustration from a longitudinal stay in a hospital.

A recreational function (passive or active form) might be filling with a movement, e. g. callanetics by teenage girls, computer games or websites searching, mobile phone games, communication between patients etc.

The most frequent controlled activities, in a category of leisure time activities of children in hospitals, are graphic activities that contribution is highly rated among hospitál staffs. For example a head nurse in Masaryk town's hospital in Jilemnice, Janoušková Marie pointed out that pedagogues of a hospital school put a great pressure on working activities; they create a lot of bright products, children are coloring their t-shirts, so that they have good experiences from a hospital environment even back home. Even during a school age child acceptance process that is staying in a department without parents, from time to time a tear is dropped, during a planning of replacement sometime can be hearted "I do not want to go home yet, I must finish the picture." Sometimes children even do not have a time for parent's visits ${ }^{2}$. A play specialist is significantly involved in fulfillment of a leisure time in a hospital with an aim in securing a rest and a recovery of sick children, if a hospital has a play specialist or schoolmistresses available. They are trying to create a homelike environment for children, occupy them, and not let them think about their injuries. The occupation in a public nursery is closely related to a school work, also it is securing a full spiritual activity of a child, and it is developing a spare time activity in graphic, esthetic, musical, and working education.

Situations that are evoking a frustration or a disappointment might occur very easily: a child is informed about unpleasant news. The child is afraid of examinations or of painful operations. Despites of an effort of hospital staff, pedagogues, game specialist, and the others, the child is stressed thanks to: staying in hospital, not improving or upsets of physical condition, the stay in a hospital is extended, leaving of friends back home - roommates or visitors, spoiled visits of parents or relatives, homesickness etc.

To compensate a disappointment and a stress help activities mentioned above.

Its role plays even friends between patients, behavior of hospital staff, and lots of other people and activities. A great joy brings for example a brief or an email from home - from friends, from schoolmates, and from a class teacher.

Pedagogical and educational functions in a leisure time fulfill homework from teachers; if it is on a volunteer base and it is not

2 Janoušková, V. Masarykova městská nemocnice v Jilemnici. retrieved 2013. from:www.detivnemocnici.cz/seznam/l/_ d03.html 
forced - it might be supported with a teacher's personality and sympathy of a student to a teacher, form of homework, help to younger friends etc.

By contemplation an age of children is the most important. By believing children it is dealt about e. g.: a prayer - alone, with a friend, brothers and sisters, parents. An issue might occur in a specific stressful situation by hard sick patients e. g.: oncology diseases. In such cases a psychologist is significantly involved.

For a communication function of the leisure time it is essential to keep in touch with a family and with peers. This fact is support with a trend of losing visiting hours of hospital departments, a possibility for parents to stay with their children during hospitalization.

Regarding the participation - children are participating on running process of a hospital, e. g. decoration of departments' walls with own drawn pictures.

The pupils also assist at preparing of various actions in a hospital or in a hospital school - trips, competitions, projects etc.

An integrative function, form a hospitalization point of view, is to a certain extent lowered, but thanks to segregation it is possible to partly eliminate this issue based on shortening of hospitalization length and based on a presence of family. In some departments e. g. psychiatry, a music therapy is held. This therapy, besides a therapeutic effect, allows a cultural development of children patients - creative realization trough arts.

Children creativity is also developed trough listing of quality music, active singing or playing some instrument, e. g. while walking in a hospital park.

Children patients are mainly allowed to leave a hospital area, especially those with a hard sickness that have to stay in beds under a continual supervision of hospitál staff. That is not encouraging them at all in their moods and psychical condition that are (Dlouhý, 2011).

So essential for a faster recovery and returning back home. That is the reason why some "good souls" are trying to bring some pieces of the outside world in - trough a nice visit that will bring in an entertaining program, presents, sweets etc.

A trip outside a hospital is highly welcome if there is permission from doctors.

This fact has already realized several employees from Brno's zoo and prepared an innovative activity as a trip for small patients of Faculty hospital Children hematology in Černá Pole on the 1st of June, 1997 - Day of children, along with their parents accompanied by hospitál staff. As Linhartová (2007) pointed out, the action had a remarkable response. It brought lost of joy and relaxation to all the participants. It helped to relax children, ease theirs stress, and involve them more in a treatment process. After the first success form a one-time action became a tradition. Children became regularly - every first Tuesday in a month - visiting animals in the zoo situated on Monks Mountain in Brno. A leaflet with "a tiger's invitation" gets children regularly for more than ten years.

Children are tolerating much better a hospitalization thanks to the trips to the animals. Thanks to the effect of stay in fresh air the children have a better appetite that is very significant by oncology patients. By drawings pictures next day after trips, children can recall experiences from the zoo visits and pleasant moments spent outside a hospitál are again recalled. A children good mood is infectious; it is transmitted to parents and medical staff (Dlouhá, 2006).

An idea to give a piece of leisure time to several volunteers and Professional even of different specializations (oncologists, university pedagogues, zoologists, nature lovers), had an external employee of Brno’s zoo prof. MVDr. Dagmar Ježková, CSc. She argued a director of the zoo MVDr. Martina Hovorku, Ph.D., a head of Children oncology clinic prof. MUDr. Jaroslav Stěrba, Ph.D., and several others into the realization of this project participating up till today (Linhartová, 2007).

In to the drawing of pictures, children parents are also often involved, especially mothers. They are recalling animals that they met a day before. They are trying to capture details of a favorite animal and afterwards they are comparing their work. Students' visits are also a pleasant relaxation even for family members that have as well as thein children a chance to relax, change thoughts, and least for a little while forget hardships connected with a hospital of their kin (Dlouhá, 2006).

During these meetings in Brno's zoo, there are not offered only a zoo attraction, but "an extraordinary kindness was handed out, a leisure time of some volunteers, even some sweets from a zoo budget for enjoyment, a joy for oncologist children patiens were offered" (Linhartová, 2007, p. 74). And it is offered not only to the children, but even to their parents and medical staff. A trip to the zoo meets definitely a relaxation function (meeting the animals, meeting their way of living and behavior), pedagogic educational function (listing to a soft splashing of water by seals' poll, watching exotic fishes bustling in aquarium in the tropical kingdom) is an ideal scene for contemplation.

If sick children are accompanied by their family or health brothers and sisters, the visit has a communicational and an integration contribution. As Linhartová (2007) pointed out, satisfied parents and grandparents of sick children that are involved in these activities are often confirming these facts in interviews with the hospital staff.

Thanks to graphic activities with pedagogic faculty students the children are also involved in the running process of departments - the pictures partly decorate children rooms and hospital halls, but what is significant, they are sending towards Mrs. Jensen in Norway within in a frame of Stonožka project. The pictures are distributed in to the whole world form Norway and gains from the project are used for buying all sorts of equipment for sick children (Bendíková, 2010).

Thanks to graphic activities children also develop their creativity and an ability to capture details of an observed phenomena or a memory on it trough drawings, batiks, linocuts, and other graphic techniques. It also contributes to their en-cultivation - a culture development of their own trough ATS (Bendíková, 2008).

On simulative meaning of animals behavior in zoo for sick children, drew attention colluviums - About not dying (may 2005) and About tiger's invitation (may 2007) held in a lecture hall of Brno's zoo. Their psychotherapeutics benefits for all that are involved in zoo visits appreciated prof. MUDr. Jiř́ Vorlíček, CSc., prof. MUDr. Jan Žaloudík, CSc. and others.

In today's sick patients medical care theories, especially in children age, there is a main principle in a complex treatment involving all complicated processes going along with a child from a beginning of medical process to the end of treatment (in an ideal state to the complete recovery). In this conception of the medical care not only a doctor is involved, but even other professionals from assisting professions and ordinary persons that are trying to keep a child in an adequate psychic condition and that are trying to ensure a child a quality utilization of leisure time. Do not expose a child to homesickness and dark thoughts on own pain and diseases and throughout this effort contribute to a faster return into a common life. All the leisure activities for sick children prepared and realized with an agrément and supervision of attending doctor and nurses, characterize a solid amount of devoted work motivated by compassion on the pain and suffering (Dlouhá, 2012).

It is necessary to highly appreciate and support them in their work, because thanks to them children are getting an opportunity to variegate the medical treatment.

They bring joy and relaxation, so that a psychical condition is improved, a quality of life is affected, and in such consequences, even a health condition.

\section{Conclusion}

The leisure time of children in hospital is a time when there is no medical examinations, medical procedures or treatments are not head of a child. It is a time hen a child eedn't to fulfill school duties and it is a time that a child can, to a certain extant (based on an environment a child is in, physical a psychical condition of a child), spent freely based on an own discretion. To not let a child be alone in unhappy thoughts about a stay in hospital and about a separation from family and friends, hospital staff and other specialists (special pedagogues, schoolmasters, psychologists, game specialists, volunteers students form high schools and universities, hospital jesters etc.) are taking care about the leisure time of children in hospital. 
Hospital staff, in a way of complex approach to the sick children treatment and seeing the treatment as bio-psycho-socio-spiritual wellbeing, welcomes these activities.

Whereas it is a matter of fact that nothing should be affecting the process of treatment and all that are involved in improving tendency of the time when is a child in a hospitál have to respect a treatment mode and all instructions of the attending hospital staff.

A good example of an extraordinary initiative of decoying a child form a diseases and from unpleasant experiences that is highly welcome from hospital staff and where is the staff even taking apart, are trips of oncology diseased children from Faculty hospital Brno in Černá pole. These activities are being held for more than ten years. In this period more than 280 children together with their parents and hospital staff participated in. The trips in to the zoo contribute to a higher quality of leisure time of sick children and they have a significant psychotherapist meaning for them.

\section{Literature:}

1. Bendíková, E. Zdravotný stav - funkčná a telesná zdatnost' adolescentov In Exercitatio Corporis - Motus Salus. Banská Bystrica: Univerzita Mateja Bela, Fakulta humanitných vied, 2008. s. 23-31.ISSN 1337-7310.

2. Bendíková, E. Iniciátori k pohybovej aktivite od predškolského veku po adolescenciu In Acta Facultatis Humanisticae Universitatis Matthiae Belii Neosoliensis. Vedy o športe: zborník vedeckých štúdií učitel'ov a doktorandov. Banská Bystrica: Univerzity Mateja Bela, fakulta humanitných vied, 2010. s. 16-22. ISSN 13477213.

3. Dlouhá, J. O jedné možnosti psychické podpory nemocného ditěte. Speciální pedagogika,1/2006, 2006. s. 21 - 28. ISSN 1211 - 2720.

4. Dlouhá., J., Dlouhý, M. Sociální opora hospitalizovaného ditěte. Praha: Univerzita Karlova, Pedagogická fakulta. 2012. 127 s. ISBN 978-80-7290-556-0.

5. Dlouhý, M. Rozvoj pozornosti a výkonové motivace u mládeže se sluchovým postižením prostřednictvím intervenčního pohybového programu. Praha: Univerzita Karlova, Pedagogická fakulta. 2011. 153 s. ISBN 978-807290-514-0.

6. Janoušková, V. Masarykova městská nemocnice $v$ Jilemnici. retrieved 2013. from: www.detivne mocnici.cz/seznam/l/1_d03.html

7. Královec, J., Královcová, M. Nadačni fond Kliček. [online] retrieved $2013 . \quad$ from: www.klicek.org/index2.html

8. Linhartová, V. Dívej, jak se šimpanz směje. Povídky z onkologické kliniky. Brno: Akademické nakladatelství CERM, 2007. ISBN 978-80-7204-513-6.

9. Němec, J. et al. Kapitoly ze sociální pedagogiky a pedagogiky volného času. Brno: Paido, 2002. ISBN 807315-012-3.

10. Opaschowski, H., W. Freizeit. Hamburk: CDV, 2001. ISBN 3-924865-35-3.

11. Pávková, J. et al. Pedagogika volného času. Teorie, praxe a perspektivy výchovy mimo vyučováni a zařizení volného času. Praha: Portál, 2008. ISBN 978-80-7367-423-6.

\section{Primary Paper Section: A}

Secondary Paper Section: AK, AM 